\title{
ANALISIS BREAK EVEN POINT USAHATANI TOMAT DI KELURAHAN LANDASAN ULIN UTARA KOTA BANJARBARU
}

\author{
(Break Event Point Analysis Of Tomato Farming In Landasan Ulin Utara \\ Village Banjarbaru City)
}

\author{
Yan Yozef Agus Suratman, dan Ahmad Syahripiadi Santosa \\ Program Studi Agribisnis Fakultas Pertanian Universitas Achmad Yani Banjarmasin \\ Jl. A. Yani KM 32,5 Banjarbaru \\ Penulis koresponden : yanyozef.agussuratman58@gmail.com,
}

Article Submitted: 26-02-2021

Article Accepted: 26-05-2021

\begin{abstract}
This study aims to: determine the technical description of tomato cultivation; know how much they cost, revenue, profit, and the break-even point of tomato farming at Landasan Ulin Utara Village, Liang Anggang District. In extracting information, surveys and observations are carried out. The method used for sampling is the census method, which is to take all the population of tomato producer farmers in Landasan Ulin Utara Village. The number of productive farmers who planted tomatoes was 25 people, then all of these tomato farmers were assigned as respondents in this study. The results showed that the land area used by the respondents was an average of 0.77 hectares and the land ownership status was property rights. The average production was $2,796 \mathrm{~kg} /$ respondent or an average $3,631.17 \mathrm{~kg} / \mathrm{ha}$ (3.63 tons / ha). The total cost was IDR 4,360,046.77 / respondent, the average fixed cost per respondent was IDR 519,446.77 and the average variable cost per respondent was IDR 3,840,600.00. The average income per respondent is IDR 13,980,000.00. The profit obtained in one production process is IDR 9,619,953.23 / respondent or the average profit per hectare is IDR 12,493,445.76. The value equivalent to the initial investment point or Break-Even Point (BEP) seen from the production volume is $143.43 \mathrm{~kg}$ and the size of the cost is IDR $717,145.44$ / respondent. At the BEP point, there will be a break-even point where the amount of sales is the same as the amount of production.
\end{abstract}

Keyword : tomato farming, cost, revenue, profit, the break-even point

\section{PENDAHULUAN}

Sebagian besar penduduk Indonesia bertumpu pada wilayah pedesaan, menyiratkan bahwa Indonesia merupakan salah satu negara dengan kawasan agraris sebagai sumber pekerjaan bagi sebagian besar penduduknya. (Rizaldi, dkk, 2021). Sejalan dengan berkembangnya jumlah dan jenis komoditi pertanian, maka usaha untuk membudidayakan komoditi pertanian tersebut selalu diarahkan untuk memperoleh hasil semaksimal mungkin. Usaha-usaha yang dilakukan untuk memperoleh produksi yang maksimal tersebut diantaranya adalah dengan intensifikasi, yaitu peningkatan produksi per satuan luas per satuan waktu dan ekstensifikasi yaitu peningkatan produksi dengan perluasan lahan/areal tanam, serta peningkatan teknologi tepat guna yang kesemuanya itu dimaksudkan sebagai usaha untuk memperbaiki taraf hidup para petani dan masyarakatnya.

Di bidang budidaya pertanian, petani harus memiliki opsi untuk menggabungkan unit produksi menjadi satu 
usaha secara keseluruhan. Oleh karena itu, dapat menghitung biaya dalam budidaya mereka. Penghasilan yang di dapat adalah tujuan fundamental yang mendorong kemajuan dalam mengembangkan usahataninya. Landasan Ulin Utara merupakan sebuah kelurahan di wilayah Kecamatan Landasan Ulin Kota Banjarbaru Provinsi Kalimantan Selatan, sebagian besar masyarakatnya hidup atau bermata pencaharian sebagai petani dengan bercocok tanam, seperti : padi, cabe rawit, tomat, kacang tanah, dan lain-lain. Usahatani tomat yang dilaksanakan oleh petani di kelurahan ini masih dilakukan secara tradisional, hal ini karena pengetahuan dan keterampilan yang terbatas serta minimnya modal yang dimiliki petani di samping mengingat usahatani tomat ini merupakan usaha sampingan.

Mengingat keberadaan komoditi tomat cukup disenangi dan berpotensi untuk terus dikembangkan, di samping itu usaha ini masih sedikit diusahakan di desa ini sehingga menarik perhatian untuk melihat dan meneliti kegiatan usahatani ini baik secara gambaran teknis maupun ekonomisnya. Kebutuhan tomat di Kalimantan Selatan pada umumnya sebagian besar masih didatangkan dari pulau Jawa, hanya sebagian kecil yang diusahakan oleh petani. Konsep analisis Break Even Point dapat membantu para petani dalam merencanakan keuntungan dan pengendalian aktivitas usaha sehingga kerugian dapat dihindarkan. Oleh karena itu penelitian ini diarahkan untuk mengetahui titik inpas usahatani tomat.

$$
\text { Berdasarkan uraian yang }
$$
diungkapkan di atas, maka disusun perumusan masalah sebagai berikut : (1) Apa gambaran khusus tentang teknis budidaya tomat di kelurahan ini. (2) Seberapa besar pengeluaran yang dikeluarkan, penerimaan, dan keuntungan usahatani tomat di kelurahan ini. Berapa besarnya nilai investasi awal atau titik impas (Break Even Point) untuk budidaya padi produsen tomat di kelurahan ini. Berdasarkan latar belakang penelitian ini, maka tujuan penelitian ini adalah untuk (1). Mengetahui gambaran secara teknis budidaya tomat ; (2). Mengetahui berapa pengeluaran, penerimaan, dan keuntungan usahatani tomat serta mengetahui nilai investasi awal atau titik impas (break even point) bagi petani produsen tomat di kelurahan ini.

\section{METODE PENELITIAN}

\section{Tempat dan Waktu}

Penelitian ini dilaksanakan pada daerah Landasan Ulin Utara di Kecamatan Liang Anggang Kota Banjarbaru Kalimantan Selatan. Pelaksanaannya dilakukan selama lebih kurang 3 (tiga) bulan yaitu mulai bulan Pebruari hingga Mei 2020, mulai tahap persiapan sampai penyusunan laporan.

\section{Data serta Sumber Data}

Data yang dicermati serta dianalisis dalam studi ini meliputi data primer serta data sekunder. Data primer merupakan informasi yang digali dari petani melalui wawancara langsung berdasarkan daftar pertanyaan/ quistioner yang sudah disiapkan. Adapun data sekunder merupakan informasi yang dirangkum dari dinas-dinas ataupun lembaga yang relevan dengan penelitian ini.

\section{Metode Penarikan Contoh}

Penelitian ini memakai cara survei dengan metode observasi. Cara penetapan petani contoh memakai metode sensus ialah mengambil seluruh petani produsen tanaman tomat di Kelurahan Landasan Ulin Utara. Diketahui populasi petani yang menanam tanaman tomat yakni 25 orang, setelah itu totalitas petani tomat yang terdapat di desa ini dijadikan selaku responden pada penelitian ini.

\section{Analisis Data}

Informasi yang berhasil didapat selanjutnya dianalisis menggunakan cara tabulasi kemudian diteruskan analisis dari segi finansial yang menyangkut 
pengeluaran, penerimaan, keuntungan, serta titik impas ( Break Even Point) usahatani tomat di Kelurahan Landasan Ulin Utara. Besarnya pengeluaran total yang digunakan dalam penyelenggaraan usahatani secara matematis dirumuskan sebagai berikut :

$$
\mathbf{T C}=\mathbf{F C}+\mathrm{VC}
$$

Dimana : $\mathrm{T}_{\mathrm{C}}=$ Total Pengeluaran $(\mathrm{Rp})$

$\mathrm{F}_{\mathrm{C}}=$ Pengeluaran Tetap $(\mathrm{Rp})$

$\mathrm{V}_{\mathrm{C}}=$ Pengeluaran Variabel $(\mathrm{Rp})$

Penerimaan total usahatani tomat pada penelitian ini dihitung dengan rumus :

$$
\mathbf{T}_{\mathbf{R}}=\begin{array}{lll}
\mathbf{P y} & \mathbf{X}
\end{array}
$$

dimana :

$\mathrm{T}_{\mathrm{R}}=$ Jumlah Penerimaan (Rp)

$\mathrm{P}_{\mathrm{y}}=$ Nilai per unit produksi $(\mathrm{Rp} / \mathrm{kg})$

$\mathrm{Y}=$ Jumlah Produksi $(\mathrm{kg})$

Adapun untuk mengetahui keuntungan digunakan rumus :

$$
\pi=T_{R}-T_{C}
$$

dimana :

$\pi=$ Keuntungan $(\mathrm{Rp})$

$T_{R}=$ Jumlah Penerimaan (Rp)

$T_{\mathrm{C}}=$ Jumlah Pengeluaran (Rp)

Nilai titik pulang pokok atau break

even point pada usahatani berdasarkan volume produksi dan penjualan (sales) dalam rupiah dapat diketahui dengan menggunakan rumus sebagai berikut (Efendi, 2016) :

$$
\mathbf{Y}=\frac{F_{C}}{P_{y}-A V_{C}}
$$

$\mathrm{Y}$ dalam satuan volume produksi $(\mathrm{kg})$

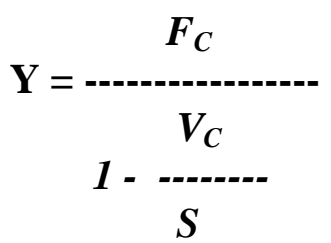

Y dalam satuan rupiah $(\mathrm{Rp})$

Dimana :

$\mathrm{Y}=$ Jumlah Produksi

$\mathrm{F}_{\mathrm{C}} \quad=$ Pengeluaran Tetap $(\mathrm{Rp})$

$\mathrm{P}_{\mathrm{y}} \quad=$ Nilai per unit produksi $(\mathrm{Rp} / \mathrm{kg})$

$$
\begin{aligned}
\mathrm{AV}_{\mathrm{C}}= & \text { Pengeluaran Variabel Rata-Rata } \\
& (\mathrm{Rp}) \\
\mathrm{VC}= & \text { Pengeluaran Variabel }(\mathrm{Rp}) \\
\mathrm{S}= & \text { Penjualan }
\end{aligned}
$$

\section{HASIL DAN PEMBAHASAN}

\section{Identitas Petani}

Umur petani tomat di daerah penelitian ini rata-rata 43,5 dengan kisaran antara 25 sampai 62 tahun. Menurut Anwar dan Fatmawati (2018), penduduk yang berusia 15 -64 tahun adalah penduduk berusia produktif.

Penelitian ini menginformasikan bahwa sebagian besar petani di daerah ini berpendidikan sedang, karena sudah mengenyam pendidikan tingkat SLTP. Pendidikan ini sangat berpengaruh terhadap petani dalam mengelola usahataninya.

Jumlah tanggungan petani tomat di daerah ini berkisar antara 0-3 orang. Hal ini sangat berpengaruh terhadap besarnya pendapatan keluarga petani. Disisi lain besarnya tanggungan jika berada di usia produktif dapat membantu tenaga kerja keluarga. Menurut Drakel (2011), tingkat produksi dan pendapatan dipengaruhi oleh jumlah tanggungan keluarga. Norfahmi, dkk (2017), kehidupan keluarga petani juga berperan penting sebagai penyedia tenaga kerja selain sebagai produsen dan konsumen. Menurut Suratman (2015), potensi yang cukup besar dalam kegiatan budidaya pertanian merupakan ketersediaan tenaga kerja dari dalam keluarga.

\section{Areal Garapan}

Areal garapan yang dimiliki petani tomat adalah berstatus milik sendiri. Sedangkan areal garapan yang digunakan untuk usahatani tomat rata-rata adalah 0,77 hektar. Luasan lahan garapan ini terlihat masih relatif kecil, namun kalau responden mampu mengelola usahataninya lebih baik, maka pendapatan responden akan lebih meningkat, hanya perlu dukungan modal yang memadai. 
Gambaran Aspek Teknis Usahatani Tomat

\section{Pengolahan Tanah}

Pengolahan tanah yang dikerjakan pada aktivitas usaha budaya tomat di Landasan Ulin Utara ini meliputi :

\section{a. Pembersihan Areal}

Sebelum dilakukan pengolahan tanah, maka areal garapan perlu dibersihkan dari tumbuhan rumput-rumputan maupun gulma serta akar-akar agar tidak mengganggu pertumbuhan tanaman tomat.

\section{b. Penggemburan Tanah}

Penggemburan tanah dilakukan agar tanah menjadi longgar sehingga pertukaran air dan udara di dalam tanah menjadi baik. Pada tanah yang longgar, penghisapan unsur hara dan pergerakan akar dengan bebas. Tanah yang sudah bersih kemudian digemburkan dengan cangkul sedalam antara $20-30 \mathrm{~cm}$, kemudian dihaluskan serta diratakan.

\section{c. Pembuatan Bedengan}

Areal tanam yang gembur ini dibiarkan selama 3 hingga 4 hari. kemudian dibuat bedengan dengan lebar antara $80-$ $100 \mathrm{~cm}$ dan panjang bedengan lebih kurang 4 - 5 meter. Bedengan dibuat menjorok ke arah jalur Timur-Barat, sehingga tanaman bisa mendapatkan cahaya matahari sebanyak yang diharapkan. Pengerjaan bedengan ini diharapkan untuk memudahkan pembuangan air yang ekstrim, mempermudah pemeliharaan dan menghindari pemadatan tanah akibat terinjak.

Menurut Nazaruddin (1993), pengolahan tanah dilakukan sampai menjadi gembur dan dibuat bedengan sebelum penanaman tomat. Jadi responden telah melakukan sesuai dengan anjuran yaitu melakukan pembersihan lahan, pengolahan tanah dan pembuatan bedengan sebelum dilakukan penanaman.

\section{Persiapan Benih dan Pembibitan}

Jenis tomat yang ditanam oleh responden di Kelurahan Landasan Ulin Utara adalah tomat dengan varietas panah merah (isi 25 gram per bungkus).
Kebutuhan benih tomat rata-rata sebanyak 8,24 bungkus (206 gram) per responden atau 267,53 gram per hektar. Sebelum ditanam benih disemaikan ditempat pembibitan yang telah disiapkan, kemudian bibit ditanam dipertanaman setelah berumur lebih kurang 30 - 40 hari. Menurut Nazaruddin (1993), kebutuhan benih tomat per ha adalah berkisar antara $300-400$ gram/ha. Jumlah benih yang dilakukan responden lebih sedikit bila dibandingkan dengan anjuran, hal ini karena pada umumnya responden tidak melalukan penyulaman tanaman.

\section{Penanaman}

Penanaman tomat yang dilakukan oleh responden di Kelurahan Landasan Ulin Utara ini pada biasanya memakai jarak tanam yang teratur Penanaman dilakukan dengan teknik memasukkan bibit( tinggi bibit \pm 15 centimeter) ke lubang tanam sekitar 1- 2 bibit per lubang. Jarak antar tanaman yang digunakan yaitu 50 centimeter x 50 centimeter; ataupun 60 centimeter x 60 centimeter. Menurut Sugeng, HR (1983), untuk memperoleh produksi maksimal, penanaman dilakukan dengan jarak tanam $60 \mathrm{~cm} \times 50 \mathrm{~cm}$ dengan banyak bibit per lubang tanam adalah 1-2 tanaman. Berdasarkan data penelitian ini, penanaman tomat yang dilakukan oleh responden boleh dikatakan sudah sesuai dengan anjuran.

\section{Pemupukan}

Pemupukan digunakan untuk menambah kekurangan unsur hara dalam tanah, dengan dilakukannya pemupukan maka tanaman secara langsung dapat memperoleh unsur hara yang tersedia dan dapat diambil oleh akar. Pupuk sangat penting untuk memperkaya kandungan hara tanah dan untuk meningkatkan produksi. Pemupukan yang dilakukan oleh responden hanya satu kali yaitu pada saat penanaman dengan menggunakan pupuk Bokashi yakni rata-rata dosis pemupukan $924 \mathrm{~kg}$ per responden atau $9.600 \mathrm{~kg}$ per ha. Pupuk Bokashi merupakan pupuk yang dibuat dari 
campuran kotoran sapi dan dedak kemudian diberi cairan EM-4. Menurut Nazaruddin (1993), pemupukan pada tanaman tomat yang baik adalah menggunakan pupuk kandang 15 - 20 ton/ha. Berdasarkan uraian di atas bahwa pemupukan yang dilaksanakan oleh responden masih belum sesuai dengan anjuran.

\section{Pemeliharaan}

Kegiatan pemeliharaan yang dilakukan pada usahatani tomat ini adalah penyiangan, pengendalian hama dan penyakit, serta penyiraman. Pada umumnya responden melakukan penyiangan pada tanaman tomat, yaitu ketika tanaman berumur 30 - 40 hari setelah tanam. Dengan demikian dapat dikatakan bahwa penyiangan terhadap tanaman tomat oleh responden belum sesuai dengan anjuran. Semestinya penyiangan pertama pada umur 15 hari setelah tanam dan yang kedua dilakukan sekaligus dengan pembumbunan pada waktu pemupukan kedua yaitu lima minggu sesudah tanam. Jenis haama penyerang tanaman tomat biasanya kutu dan ulat daun. Secara bergerombol kutu daun menyerang tunas muda tanaman tomat, sehingga daun yang terserang nampak mengkerut dan melingkar. Pengendalian/pemberantasan yang dilakukan dengan menggunakan matador dengan dosis $250 \mathrm{ml} / \mathrm{ha}$. Penyiraman dilakukan apabila tidak turun hujan, disamping itu penyiraman umumnya dilaksanakan pada waktu pagi dan sore hari.

\section{Panen}

Pemanenan hasil usahatani tomat dilakukan pada umur lebih kurang 100 hari setelah tanam dengan mengetahui ciri-ciri buah tomat pada areal pertanaman. Ciri-ciri buah masak yakni terlihat buah tomat berwarna merah. Cara panen tomat adalah dengan cara memetik langsung buah tomat yang sudah masak tersebut dengan menggunakan tangan. Produksi tomat ratarata di Kelurahan Landasan Ulin Utara adalah $2.796 \mathrm{~kg} / \mathrm{responden}$ atau 3.631,17 kg/hektar. Menurut Nazaruddin (1993), produksi tomat yang baik berkisar antara 5 10 ton per hektar. Apabila dibandingkan dengan produksi tomat di Kelurahan Landasar Ulin Utara ini maka dapat dikatakan masih rendah, hal ini diakibatkan kurang modal dan teknis bercocok tanam terutama tentang pemupukan yakni dosis dan jenis pupuk yang digunakan, pencegahan hama-penyakit, dan lain-lain yang menunjang teknis budidaya tanaman tomat perlu diperbaiki.

\section{Aspek Finansial Usahatani Tomat}

Pengeluaran usahatani

ini sesungguhnya adalah nilai dari semua masukan yang dikorbankan, seberapapun kecil atau sedikitnya keterlibatan dari awal proses produksi hingga didapatnya hasil usahatani. Pengeluaran dalam suatu usaha budidaya pertanian nantinya akan berpengaruh pada nilai perolehan atau pendapatan usahatani tersebut. Pengeluaran petani yang semakin besar, mengakibatkan pendapatan yang diperoleh semakin kecil, dan sebaliknya.

Adapun jenis pengeluaran yang diperhitungkan oleh petani tomat di Kelurahan Landasan Ulin Utara meliputi pengeluaran tetap dan pengeluaran variabel.

\section{Pengeluaran Tetap}

\section{a. Pajak lahan}

Besarnya pajak lahan yang berlaku di Kelurahan Landasan Ulin Utara adalah Rp. 7.500,- per hektar. Perhitungan pajak lahan adalah besarnya pajak lahan dibagi 12 bulan dikalikan dengan satu kali proses produksi. Besarnya pengeluaran yang dibayarkan untuk pajak lahan rata-rata adalah sebesar Rp. 5.775,00 per responden.

\section{b. Nilai Susut alat dan perlengkapan}

Pengeluaran susut alat dan perlengkapan merupakan pengeluaran terhadap alat yang dipakai tiap sekali proses produksi, namun susut alat ini hanya dikenakan untuk peralatan yang digunakan lebih dari sekali proses produksi. Pengeluaran susut alat ini diperhitungkan dengan metode garis lurus (Straight Line 
Method), yaitu besarnya harga pembelian dikurangi nilai sisa dibagi umur ekonomis alat dikali lama pemakaian.
Nilai Susut Alat dan perlengkapan rata-rata pada usahatani tomat di Landasan Ulin Utara adalah Rp. 247.626,67 per responden ( Tabel 1).

Tabel 1. Rata-rata Pengeluaran Susut Alat dan Perlengkapan PetaniTomat Di Landasan Ulin Utara

\begin{tabular}{llccc}
\hline No. & \multicolumn{1}{c}{$\begin{array}{c}\text { Jenis Alat } \\
(\text { Buah })\end{array}$} & $\begin{array}{c}\text { Banyaknya } \\
(\text { Buah })\end{array}$ & $\begin{array}{c}\text { Pengeluaran Susut Alat } \\
\text { Rata-Rata }(\mathrm{Rp})\end{array}$ & $\begin{array}{c}\text { Persentase } \\
(\%)\end{array}$ \\
\hline 1. & Cangkul & 1,68 & $3.500,00$ & 1,41 \\
2. & Parang & 2,08 & $1.386,67$ & 0,56 \\
3. & Arit & 1,64 & $1.913,33$ & 0,77 \\
4. & Handsprayer & 1,00 & $4.000,00$ & 1,62 \\
5. & Karung & 5,24 & 436,67 & 0,02 \\
6. & Ajir & 2.310 & $231.000,00$ & 93,44 \\
7. & Tali rapia & 0,77 & $5.390,00$ & 2,18 \\
\hline \multicolumn{2}{r}{ Jumlah } & & & 100,00 \\
\hline
\end{tabular}

Sumber: Pengolahan Data Primer, 2020.

Mengacu dari data pada Tabel 1 di atas, terlihat bahwa pengeluaran untuk susut alat terbesar untuk penyediaan ajir yaitu sebesar Rp. 231.000,00 (93,44 \%). Adapun untuk pengadaan karung adalah yang terkecil yaitu Rp. 436,67 (0,02 \%).

\section{c. Pengeluaran sewa lahan}

Pengeluaran sewa lahan dihitung berdasarkan pengeluaran sewa yang berlaku di daerah ini. Harga sewa untuk lahan seluas satu hektar selama satu musim tanam adalah Rp. 25.000,-. Pengeluaran ini dimasukkan dalam pengeluaran tetap karena lahan merupakan milik petani sendiri. Pengeluaran sewa lahan rata-rata adalah sebesar Rp. 18.500,00 per responden.

\section{d. Bunga modal}

Bunga modal dihitung berdasarkan tingkat bunga yang berlaku atau ditetapkan oleh BRI yaitu $18 \%$ per tahun atau setara dengan $1,5 \%$ per bulan. Bunga modal ini dimasukkan dalam pengeluaran tetap. Besarnya bunga modal pada usahatani tomat ini rata-rata adalah sebesar Rp. 246.795,10 per responden.

Pengeluaran tetap dalam penelitian ini terdiri dari pengeluaran susut alat dan perlengkapan, pajak lahan, sewa lahan, dan bunga modal. Besarnya pengeluaran tetap rata-rata pada usaha budidaya tomat di Kelurahan Landasan Ulin Utara adalah Rp. 519.446,77 per responden (Tabel 2).

Tabel 2. Rata-rata Pengeluaran Tetap Petani Tomat Di Landasan Ulin Utara

\begin{tabular}{|c|c|c|c|}
\hline No. & Komponen Pengeluaran Tetap & $\begin{array}{c}\text { Pengeluaran Tetap } \\
\text { Rata-Rata (Rp) }\end{array}$ & $\begin{array}{c}\text { Persentase } \\
(\%)\end{array}$ \\
\hline 1. & Susut Alat alat \& perlengkapan & $247.626,67$ & 47,82 \\
\hline 2. & Pajak lahan & $5.775,00$ & 1,11 \\
\hline 3. & Sewa lahan & $18.500,00$ & 3,56 \\
\hline 4. & Bunga modal & $246.795,10$ & 47,51 \\
\hline & Jumlah & $519.446,77$ & 100,00 \\
\hline
\end{tabular}

Sumber : Pengolahan Data Primer, 2020. 
Pengeluaran Variabel

Pengeluaran Saprodi

Pengeluaran saprodi selama proses produksi meliputi pengeluaran benih, pupuk, dan herbisida. Besarnya pengeluaran saprodi rata-rata usahatani tomat yaitu $\mathrm{Rp}$. 2.971.800,- per responden atau Rp. 3.859.480,52 per hektar (Tabel 3).

Tabel 3. Rata-rata Pengeluaran Saprodi Petani Tomat di Landasan Ulin Utara.

\begin{tabular}{|c|c|c|c|}
\hline No. & $\begin{array}{c}\text { Komponen Pengeluaran Sarana } \\
\text { Produksi }\end{array}$ & $\begin{array}{l}\text { Pengeluaran Saprodi } \\
\text { Rata-Rata (Rp) }\end{array}$ & $\begin{array}{l}\text { Persentase } \\
(\%)\end{array}$ \\
\hline 1. & Benih & $164.800,00$ & 5,55 \\
\hline 2. & Pupuk Bokashi & $2.772 .000,00$ & 93,27 \\
\hline 3. & Matador & $35.000,00$ & 1,18 \\
\hline & Jumlah & $2.971 .800,00$ & 100,00 \\
\hline
\end{tabular}

Sumber : Pengolahan Data Primer, 2020.

\section{Pengeluaran tenaga kerja}

Pengeluaran tenaga kerja diperhitungkan berdasarkan pada tingkat upah yang berlaku pada saat penelitian yakni perhitungan didasarkan pada hari kerja orang (HKO). Tingkat upah yang berlaku di wilayah penelitian untuk 1 (satu) HKO adalah sebesar Rp. 40.000,- Berdasarkan perhitungan rata-rata pengeluaran tenaga kerja pada usahatani tomat ini adalah Rp. $868.800,00$ per responden atau $\mathrm{Rp}$. 1.128.311,69 per hektar.

Pengeluaran variabel pada usahatani tomat terdiri dari pengeluaran saprodi dan tenaga kerja. Besarnya pengeluaran variabel rata-rata petani tomat adalah Rp.3.840.600,00 per responden (Tabel 4).

Tabel 4. Rata-rata Pengeluaran Variabel Petani Tomat Di Landasan Ulin Utara

\begin{tabular}{llcc}
\hline No. & $\begin{array}{c}\text { Komponen Pengeluaran } \\
\text { Variabel }\end{array}$ & $\begin{array}{c}\text { Rata-rata Pengeluaran } \\
\text { Variabel }(\mathrm{Rp})\end{array}$ & $\begin{array}{c}\text { Persentase } \\
(\%)\end{array}$ \\
\hline 1. & Sarana Produksi & $2.971 .800,00$ & 77,38 \\
2. & Tenaga Kerja & $868.800,00$ & 22,62 \\
\hline & Jumlah & $3.840 .600,00$ & 100,00
\end{tabular}

Sumber : Pengolahan Data Primer, 2020.

\section{Pengeluaran Total}

Pengeluaran total merupakan jumlah keseluruhan pengeluaran dalam kegiatan usahatani pada satu proses produksi yaitu jumlah pengeluaran tetap dan pengeluaran variabel. Besarnya pengeluaran total ratarata pada usahatani tomat adalah $\mathrm{Rp}$. 4.360.046,77 per responden atau $\mathrm{Rp}$. 5.662.398,40 per hektar (Tabel 5).

Tabel 5. Pengeluaran Total Rata-Rata Petani Tomat di Landasan Ulin Utara

\begin{tabular}{llcc} 
No. & Komponen Pengeluaran Total & $\begin{array}{c}\text { Rata-rata Pengeluaran Total } \\
(\mathrm{Rp})\end{array}$ & $\begin{array}{c}\text { Persentase } \\
(\%)\end{array}$ \\
\hline 1. & Pengeluaran Tetap & $519.446,77$ & 13,53 \\
2. & Pengeluaran Variabel & $3.840 .600,00$ & 86,47 \\
\hline \multicolumn{1}{c}{ Jumlah } & $4.360 .046,77$ & 100,00
\end{tabular}

Sumber : Pengolahan Data Primer, 2020. 


\section{Penerimaan}

Penerimaan usahatani tomat dapat diperhitungkan dari banyaknya produksi tomat dikali dengan harga yang berlaku di tempat penelitian. Produksi rata-rata yang diperoleh petani tomat di wilayah penelitian adalah $2.796 \mathrm{~kg} /$ responden tiap musim tanam dengan harga jual per kilogram adalah Rp. 5.000,. Dengan demikian penerimaan rata-rata usahatani tomat adalah $\mathrm{Rp}$. 13.980.000,00 tiap responden atau $\mathrm{Rp}$. 18.155.844,16 per hektar. Harga dan jumlah produksi yang diperoleh responden sangat berpengaruh terhadap besarnya penerimaan usahatani. Jika produksi meningkat dengan asumsi bahwa harga komoditas tersebut tidak berubah maka penerimaan akan meningkat. Begitu juga sebaliknya apabila total produksi menurun dengan anggapan bahwa harga komoditas tidak berubah maka penerimaanpun jadi berkurang.

\section{Keuntungan}

Keuntungan merupakan hasil pengurangan dari penerimaan total (TR) dengan pengeluaran total (TC) dalam satu kali produksi. Penerimaan rata-rata usahatani tomat diketahui Rp. 13.980.000,00 per responden, sedangkan pengeluaran total rata-rata $\mathrm{Rp} .4 .360 .046,77$ per responden, maka dari hasil pengurangan didapatkan keuntungan ratarata Rp. 9.619.953,23 per responden atau Rp. 12.493.445,76 per hektar (Tabel 6).

Tabel 6. Keuntungan Rata-Rata Petani Tomat Di Landasan Ulin Utara

\begin{tabular}{lccc}
\hline No. & Uraian & $\begin{array}{c}\text { Rata-Rata } \\
\text { (Rp/responden) }\end{array}$ & $\begin{array}{c}\text { Per Hektar } \\
(\mathrm{Rp} / \mathrm{ha})\end{array}$ \\
\hline 1. & Penerimaan & $13.980 .000,00$ & $18.155 .844,16$ \\
2. & Pengeluaran Total & $4.360 .046,77$ & $5.662 .398,40$ \\
\hline & Keuntungan & $9.619 .953,23$ & $12.493 .445,76$
\end{tabular}

Sumber : Pengolahan Data Primer, 2020.

\section{Analisis Break-Even Point}

Analisis break even point (BEP) adalah salah satu bentuk analisis yang digunakan dalam aspek keuangan untuk menentukan ukuran produksi suatu unit usaha agar dapat menghitung keuntungan yang diharapkan petani, sehingga dapat mempertimbangkan apakah usaha yang sedang dilakukan dapat diteruskan atau tidak.

Hasil pengolahan informasi yang diperoleh dan di analisis, nilai titik pulang pokok atau break even point (BEP) dilihat dari volume produksi sebesar $2.796 \mathrm{~kg}$ dan jumlah penerimaan atau hasil penjualan sebesar Rp 717.145,44/responden, artinya usahatani tomat sudah bisa impas, apabila nilai penerimaan total sebesar $\mathrm{Rp}$ 717.145,44/responden dengan jumlah produksi $2.796 \mathrm{~kg} /$ responden. Usahatani tomat yang diusahakan di Landasan Ulin Utara ini ternyata penerimaan total lebih besar dari pengeluaran totalnya sehingga usahatani tomat menguntungkan. Penerimaan total rata-rata per responden adalah Rp 13.980.000,00 dan volume produksi rata-rata per responden sebesar 2.796 kglebih besar dari nilai BEP yaitu rata-rata penjualan sebesar $\mathrm{Rp}$ 717.145,44/responden dan nilai BEP berdasarkan volume produksi tomat rata-rata sebesar $2.796 \mathrm{~kg} / \mathrm{responden.} \mathrm{Secara} \mathrm{grafik}$ titik BEP (Break Even Point) dapat dilihat Gambar 1. 


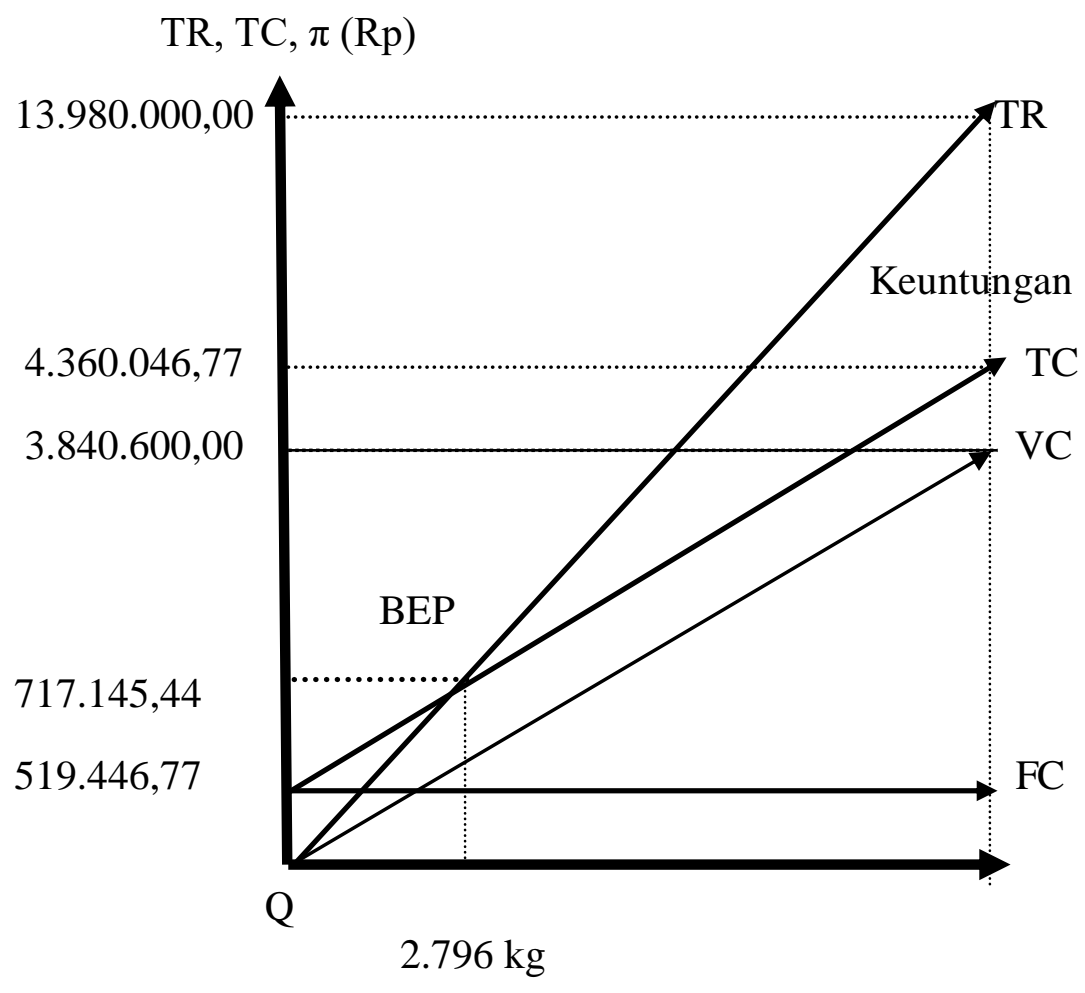

Gambar 1. Kurva Break Even Point (BEP) Usahatani Tomat

Pada Gambar 1. diketahui bahwa usahatani tomat diperoleh nilai rata-rata break even point dilihat dari volume produksi sebesar $2.796 \mathrm{~kg} /$ responden dan dari hasil penjualan (penerimaan) sebesar Rp 717.145,44 /responden. Pada titik itulah break even point terjadi, artinya apabila produksi di bawah dari titik impas (BEP) maka usahatani akan mengalami kerugian. Sebaliknya apabila usahatani tomat dapat memproduksi lebih besar atau lebih tinggi dari nilai BEP maka usahatani tomat akan mengalami keuntungan.

Berdasarkan data pada penelitian ini dan gambaran grafik kurva break even point, maka usahatani tomat yang diusahakan di Kelurahan Landasan Ulin Utara ini mampu menghasilkan keuntungan sehingga perlu dikembangkan lebih lanjut agar keuntungan diperoleh lebih optimal.

\section{KESIMPULAN DAN SARAN}

\section{Kesimpulan}

Atas dasar hasil penelitian ini, maka dapat ditarik suatu kesimpulan, yaitu :

1. Penyelenggaraan usahatani tomat di tempat penelitian ini umumnya cukup baik, yaitu dengan menanam varietas unggul. Luas lahan yang digunakan petani responden rata-rata 0,77 hektar dan status kepemilikan lahan adalah hak milik. Produksi tomat rata-rata sebesar $2.796 \mathrm{~kg} / \mathrm{responden}$ atau rata-rata $3.631,17 \mathrm{~kg} / \mathrm{ha}(3,63 \mathrm{ton} / \mathrm{ha})$.

2. Pengeluaran total rata-rata sebesar $\mathrm{Rp}$ 4.360.046,77 /responden, pengeluaran tetap rata-rata sebesar Rp 519.446,77 per responden, dan pengeluaran variabel rata-rata sebesar $\mathrm{Rp} \mathrm{3.840.600,00} \mathrm{tiap}$ responden. Penerimaan rata-rata $\mathrm{Rp}$ 13.980.000,00 per responden atau ratarata $\mathrm{Rp} 18.155 .844,16$ per hektar. 
Keuntungan yang diperoleh dalam satu kali proses produksi adalah $\mathrm{Rp}$ 9.619.953,23 tiap responden atau ratarata sebesar $\mathrm{Rp} 12.493 .445,76$ per hektar. Nilai Titik Impas atau break even point (BEP) dilihat dari volume produksi adalah sebesar $2.796 \mathrm{~kg}$ dengan total penjualan sebesar Rp 717.145,44 tiap responden. Pada titik BEP tersebut akan terjadi titik impas dimana jumlah penjualan sama dengan jumlah produksi.

\section{DAFTAR PUSTAKA}

Anwar, K dan Fatmawati, 2018. Pengaruh Jumlah Penduduk Usia Produktif, Kemiskinan, dan Inflasi terhadap Pertumbuhan Ekonomi di Kabupaten Bireuen. Jurnal Ekonomi Regional Unimal, 1 (1): 15-22.

Drakel.A, 2011. Kajian Usahatani Tanaman Tomat Terhadap Produksi dan Pendapatan Petani (Studi kasus di Desa Golago Kusuma Kecamatan Jailolo Timur Kabupaten Halmahera Barat). Jurnal Ilmiah Agribisnis dan Perikanan (Agrikan UMMUTernate), 4 (2): 31-36.

Efendi, Y, 2016. Analisis Usahatani Tomat (Lycoparsicum esculentum Mill) Di Desa Mandesan Kecamatan Selopuro Kabupaten Blitar, Jurnal Viabel Pertanian, 10(2); 51-61.
Nazaruddin, 1993. Sayuran Dataran Rendah. Penerbit Swadaya. Jakarta.

Norfahmi, F; Kusnadi, N; Nurmalina, R; dan Winandi,R, 2017 . Analisis Curahan Kerja Rumah Tangga Petani Pada Usahatani Padi dan Dampaknya Terhadap Pendapatan Keluarga. Jurnal Ilmiah Informatika Pertanian. $26(1) ; 13-22$.

Rizaldi M ; Evverson Ruaw ; Mellisa Lady Gisela Tarore. 2021. Analisis Break Even Point (BEP) usahatani Tomat di Desa Taraitaki Kecamatan Langowan Kabupaten Minahasa. Jurnal Ilmiah Agri-Sosial Ekonomi, Unsrat . ISSN, (p), 1907-4298, ISSN (e) 2685-063X. Terakreditasi Nasional, Sinta 5, Volume 17 Nomor 1. Januari 2021; 82-95.

Sugeng HR, 1983. Bercocok Tanam Sayuran. Penerbit Aneka Ilmu. Semarang.

Suratman, Y.Y.A, 2015. Kontribusi Tenaga Kerja Dalam Keluarga Terhadap Pendapatan Usahatani Terong (Solanum melongena, L) di Kelurahan Landasan Ulin Utara Kecamatan Liang Anggang, Kota Banjarbaru. Zira'ah. 40 (3); 218-225. 